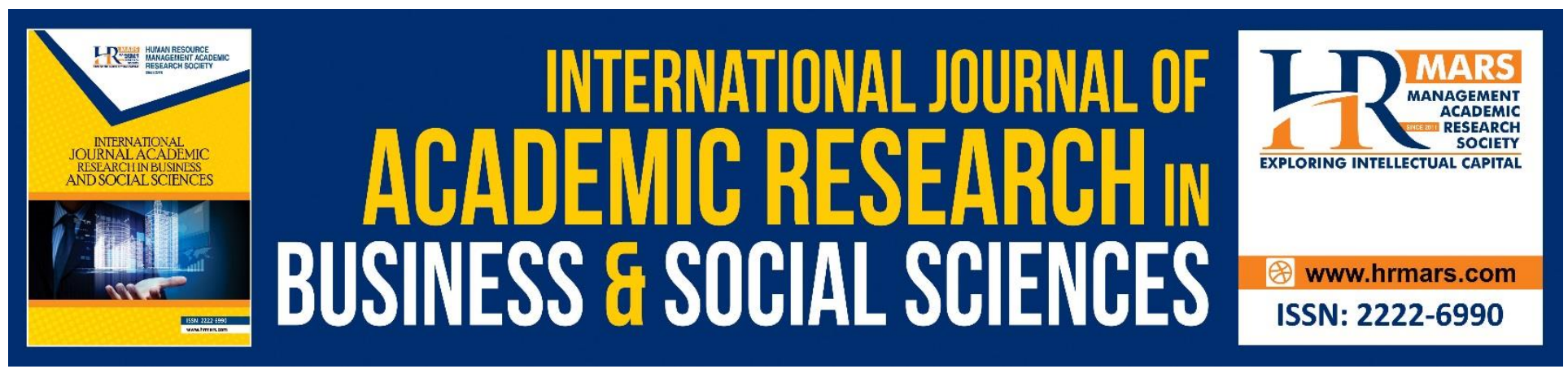

\title{
Factors Influencing Safety Performance at the Construction Site
}

Saida Farhanah Sarkam, Lily Shahzlyn Shaharuddin, Bushra Mohd Zaki, Nik Rozila Nik Mohd Masdek, Noor Junaini Arwin Yaacob, Musramaini Mustapha

To Link this Article: http://dx.doi.org/10.6007/IJARBSS/v8-i9/4680 DOI: $\quad 10.6007 /$ IJARBSS/v8-i9/4680

Received: 13 August 2018, Revised: 06 Sept 2018, Accepted: 29 Sept 2018

Published Online: 13 October 2018

In-Text Citation: (Sarkam et al., 2018)

To Cite this Article: Sarkam, S. F., Shaharuddin, L. S., Za, B. M., Masdek, N. R. N. M., Yaacob, N. J. A., \& Musramaini Mustapha. (2018). Factors Influencing Safety Performance at the Construction Site. International Journal of Academic Research in Business and Social Sciences, 8(9), 1057-1068.

Copyright: @ 2018 The Author(s)

Published by Human Resource Management Academic Research Society (www.hrmars.com)

This article is published under the Creative Commons Attribution (CC BY 4.0) license. Anyone may reproduce, distribute, translate and create derivative works of this article (for both commercial and non-commercial purposes), subject to full attribution to the original publication and authors. The full terms of this license may be seen

at: http://creativecommons.org/licences/by/4.0/legalcode

Vol. 8, No. 9, September 2018, Pg. 1057 - 1068

http://hrmars.com/index.php/pages/detail/IJARBSS

JOURNAL HOMEPAGE

Full Terms \& Conditions of access and use can be found at http://hrmars.com/index.php/pages/detail/publication-ethics 


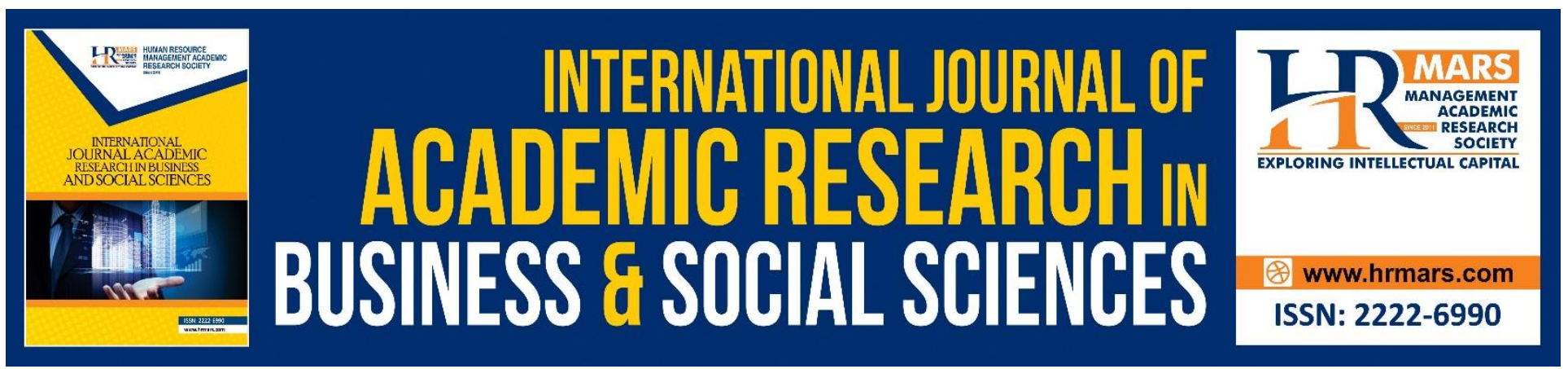

\title{
Factors Influencing Safety Performance at the Construction Site
}

\author{
Saida Farhanah Sarkam
}

Faculty of Business and Management, UiTM Melaka, Alor Gajah Campus, Melaka, Malaysia

Lily Shahzlyn Shaharuddin

Faculty of Business and Management, UiTM Melaka, City Campus, Melaka, Malaysia

\section{Bushra Mohd Zaki}

Faculty of Business and Management, UiTM Melaka, Alor Gajah Campus, Melaka, Malaysia

\section{Nik Rozila Nik Mohd Masdek}

Faculty of Business and Management, UiTM Melaka, Alor Gajah Campus, Melaka, Malaysia

Noor Junaini Arwin Yaacob

Faculty of Business and Management, UiTM Pahang, Raub Campus, Pahang, Malaysia

\section{Musramaini Mustapha}

Faculty of Business and Management, UiTM Pahang, Jengka Campus, Pahang, Malaysia

\begin{abstract}
The construction industry plays a vital role in the Malaysian economic sector. However, statistics show that the number of accidents has been rising over the years, especially at construction sites. Thus, the research aims: 1) to determine the relationship between safety awareness, time barriers, and management commitment towards safety performance at a construction site; and 2) to identify the most influential factor for safety performance at a construction site. Seventy-three construction site workers are selected as the survey respondents, including site managers and safety officers. The sampling technique used is proportionate stratified random sampling. The findings of this research show that safety awareness is the most influential factor that affects safety performance at the construction site while management commitment and time barriers positively influence safety
\end{abstract}


INTERNATIONAL JOURNAL OF ACADEMIC RESEARCH IN BUSINESS AND SOCIAL SCIENCES Vol. 8, No. 9, Sept. 2018, E-ISSN: 2222-6990 (c) 2018 HRMARS

performance. Therefore, the research proposes for the construction companies to implement regular inspection at the construction site, conduct proper training for site employees, and increase effective communication between employee-employer to improve the safety awareness among the company's employees. It is hoped that by improving the safety awareness of the employees, the rate of occupational accidents could be reduced.

Keywords: Safety Performance, Occupational Safety And Health, Construction Industry, Safety Awareness, Management Commitment

\section{Introduction}

Since 1999, the construction sector has remained the fastest growing industry in the economic sector. This is because the construction industry plays a major role in the development of Malaysia. Specifically, the sector makes a huge contribution to the Malaysian Gross Domestic Product (GDP). The construction industry grew by 8.2 per cent, or RM140 billion in 2015 and 7.4 per cent, or RM166 billion in 2016. Meanwhile, in the third quarter of 2017, the industry's growth was recorded at 6.1 per cent, and it was estimated to increase by the end of the year (Bernama, 2017).

Similar to other industries, the construction industry needs to develop its Occupational Safety and Health (OSH) policy. The OSH policy is enforced by the government as a rule that should be followed at construction sites. The OSH policy is important as it facilitates the investigation of the causes of serious occupational accidents and work-related diseases, engages in product control, and is responsible for occupational safety and health enforcement at the initiative of the customer and other players (OSHA, 2017). Safety is a very crucial issue, especially in the construction industry. However, many construction firms ignore and do not take serious action on the safety issues. The construction industry has one of the highest accident occurrences in the manufacturing industry, which makes the industry deemed unsafe (CIDB, 2018). There are high injury and death rates in the construction industry (Cheng et al., 2012; Wong et al., 2015) while the construction site is one of the most dangerous workplaces due to the high accidents rates (Ahmad et al., 2000; Masood \& Choudhry, 2011).

Since 2016, several accidents were reported at the construction sites and the number has been increasing every year. For example, in an accident at a construction site in Hulu Selangor, one person died, and four were injured after a metal scaffolding at the site fell on the workers (Zack, 2018). Besides, the number of accidents at construction sites is rising. According to the statistics from the Social Security Organization (SOCSO), 7,338 accidents were reported in the construction industry in 2016 compared with 4,330 cases in 2011, showing an increasing trend of 69 per cent over five years (Thye, 2018).

Scholars have discussed about the safety awareness factor that affects safety performance (Nawi et al., 2016), time barriers factor (Couto et al., 2017), and management commitment factor (Durdyev et al., 2017). However, there is a lack of research focusing on these three factors simultaneously in a safety performance study. Besides that, the study is important because it aims to identify the three factors from the perspective of site workers and site supervisors. Thus, the research objectives are: 
INTERNATIONAL JOURNAL OF ACADEMIC RESEARCH IN BUSINESS AND SOCIAL SCIENCES Vol. 8, No. 9, Sept. 2018, E-ISSN: 2222-6990 @ 2018 HRMARS

1) to determine the relationship between safety awareness, time barriers, and management commitment towards safety performance at a construction site; and 2) to identify the most influential factor of safety performance at a construction site.

\section{Literature Review}

\section{A. Safety Performance}

The construction industry has faced a wide range of challenges especially due to the occurrences of accidents or incidents or hazard at the site. The main cause of accidents is poor safety performance of the workers from a combination of contributing causes (Nawi et al., 2016). Therefore, a safety programme is needed to ensure and encourage better safety performance at construction sites. Safety programmes are key for avoiding work-related accidents and injuries. One has to be alert of the surrounding to prevent unwanted accidental events. Safety is also identified as one of the major factors that affects the image of the project manager and the organisation itself (Khan et al., 2015).

According to Nawi et al. (2016), there are four categories of factors affecting safety performance that should be focused on, which are: 1) management, 2) safety culture, 3) behaviour, and 4) awareness. On the other hand, Couto et al. (2017) highlighted time barriers as the factor affecting safety performance at construction sites. Safety performance can be influenced by factors including top management's and project managers' poor safety awareness, poor safety resource, lack of training, and reckless operations (Tam, Zeng, \& Deng, 2004).

\section{B. Safety Awareness}

The lack of awareness can be a problem or factor that affects safety performance. Self-reporting of an accident should be a culture of the workers at the workplace. The information on accidents can be used as an aid for risk assessment and to develop solutions to the problem. It can also prevent injuries and control costs from accidental losses. However, the accidents reported were mostly ignored or denied. This was because they were scared of the consequences that their supervisors or the person in charge will scold or punish them (Yilmaz \& Çelebi, 2015).

There is a lack of awareness in recording the accidents that have occurred. There is no toolbox meeting, less common sense of the worker, and no on-site inspection. The toolbox meeting is a gathering that involves all construction workers and supervisors to discuss on health and safety matters, which should be held daily to educate and remind the workers of safety and potential hazards (Ghani et al., 2008). Moreover, the Occupational Safety and Health Administration (OSHA) requires the safety officer at the construction site to record and report the accident information on a form known as Occupational Injuries and IIIness Annual Survey Form (OSH, 2017). The construction management needs to be aware of the accident and record it to establish a better course of action for future accident or incident prevention. If the accident is not reported or detailed, it is impossible to identify the cause of minor accidents (Yilmaz \& Çelebi, 2015). 
INTERNATIONAL JOURNAL OF ACADEMIC RESEARCH IN BUSINESS AND SOCIAL SCIENCES Vol. 8, No. 9, Sept. 2018, E-ISSN: 2222-6990 @ 2018 HRMARS

\section{Time Barriers}

One of the factors that may cause an occupational accident is related to the time barriers. A tight construction schedule is a serious matter at a construction site (Couto et al., 2017). The outcomes of failing to meet deadlines are often severe and difficult to solve, causing losses for the clients, often reducing profit for promoters, and worsening safety condition at the site. The industry's goal is to complete the project on time even though sometimes it may neglect the safety issues (Wong et al., 2015).

To complete the tasks in the shortest possible time, the workers have to work for excessive hours, and they often disregard safety. Besides, long working hours will increase fatigue and lead to poor concentration and decision making and therefore worsen the risk of injury (Haslam et al., 2005). Due to time pressure of projects, there is a lack of Occupational Safety and Health (OSH) training and education which significantly increases the occupational risk (Kelloway \& Cooper, 2011). A good and ample timeline of a project, including sufficient time for the workers to attend training, would prevent occupational accidents (Couto et al., 2017). Tam Zeng and Deng (2004) agreed that excessive overtime works and time barriers lead to poor safety performance of a company.

\section{Management Commitment}

The management commitment component includes the top management's commitment, awareness, communication, and supervision. The management team has the opportunity to control occupational risks and employ a behavioural-based management system to reduce the accidents or incidents at the construction site (Lin \& Mills, 2001). Moreover, the management has to actively support the safety efforts in the company, and they should not solely put the blame for occupational accidents on the employees. Furthermore, poor safety awareness of the top management may lead to poor safety performance (Abdul-Rashid et al., 2007; Akson \& Hadikusumo, 2008).

Difficulties in communication with foreign workers can also cause accidents at the construction site (Hsu et al., 2014). The safety issue faced is due to some of the workers who do not speak or understand the local language. Effective communication might help both parties, namely the safety supervisor and the worker, to have better coordination at the construction site (Ghani et al., 2008; Haslam et al., 2005). According to Peyton and Rubio (1991), good communication affects the implementation of the safety programme; when the management communicates openly to the worker, the worker will report on unsafe working practices and hazardous environment. In turn, the management can communicate their concerns about safety to gain employees' awareness.

The involvement of all management team members in the safety and health culture is crucial for achieving positive beliefs, practices, norms, and attitudes. It means that the management team plays an important role in determining the safety and health of the worker or manpower as well as at the construction site. Akson and Hadikusumo (2008) and Rowlison (2003) mentioned that employees usually imitate or copy and follow the actions of management. Hence, the management is required to set a positive standard of safety behaviour for all the workers. 
INTERNATIONAL JOURNAL OF ACADEMIC RESEARCH IN BUSINESS AND SOCIAL SCIENCES Vol. 8, No. 9, Sept. 2018, E-ISSN: 2222-6990 (C) 2018 HRMARS

\section{Theoretical Framework}

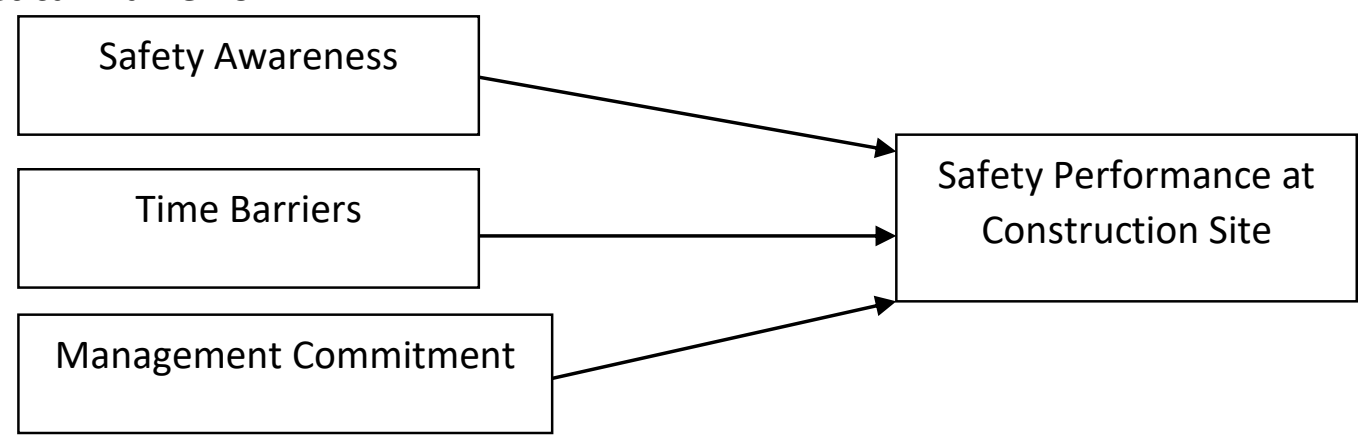

Figure 1: Theoretical Framework of the Study

In Figure 1, the dependent variable is safety performance at the construction site while the independent variables are safety awareness, time barriers, and management commitment. The independent variables are the factors influencing the dependent variable, which is safety performance at the construction site.

\section{Research Methodology}

A quantitative methodology was adopted to answer the research questions. The survey method was used to obtain the required data. Survey research involves the study of a specified population by extracting the required sample to represent the population that is being studied (Sekaran \& Bougie, 2016). The researchers selected a construction site with 89 employees for the study. Krejcie and Morgan (1970) suggested 73 people are sufficient as the sample size. The sampling frame used was the Construction Industry Development Board (CIDB) Green Book of the employees. The researchers used stratified random sampling to select the respondents needed for the study. Table 1 shows the calculation involved in the sampling procedure and Table 2 shows the sources of the questionnaire, which was adapted from past research.

Table 1: Calculation of Proportionate Stratified Random Sampling

\begin{tabular}{|l|c|c|}
\hline Position in organisation & Element & $\begin{array}{c}\text { Number of subjects in } \\
\text { element ( 82\% of element) }\end{array}$ \\
\hline Site Manager & 8 & 6 \\
\hline Safety Officer & 2 & 2 \\
\hline Manpower & 79 & 65 \\
\hline Total & $\mathbf{8 9}$ & $\mathbf{7 3}$ \\
\hline
\end{tabular}


INTERNATIONAL JOURNAL OF ACADEMIC RESEARCH IN BUSINESS AND SOCIAL SCIENCES Vol. 8, No. 9, Sept. 2018, E-ISSN: 2222-6990 @ 2018 HRMARS

Table 2: Sources of Questionnaire

\begin{tabular}{|c|c|c|}
\hline VARIABLE & ITEM IN QUESTIONNAIRE & ORIGINAL SOURCE(S) \\
\hline Demographic Profile & 4 & Designed by researcher \\
\hline Safety Performance & 4 & 1) Nawi et al. (2016). \\
\hline Safety Awareness & 4 & $\begin{array}{c}\text { 2) Durdyev et al. (2017). } \\
\text { 3) Masood and Choudhry } \\
\text { (2011). }\end{array}$ \\
\cline { 1 - 2 } Mane Barriers & 4 & $\begin{array}{c}\text { (20)ment } \\
\text { Commitment }\end{array}$ \\
\hline
\end{tabular}

\section{Findings}

To answer the research questions and to achieve the research objectives, the researchers utilised the IBM-SPSS software for data analysis. Table 3 shows the demographic profile of the respondents. Most of the workers were $19-28$ years old (35.6\%) and $89 \%$ of the workers were Malaysians. There were six site managers, two safety officers, and 65 general workers as respondents. Most of them have worked for more than ten years at the construction company.

Table 3: Demographic Profile of the Respondents

\begin{tabular}{|c|c|c|}
\hline Demographic Characteristic & Frequency & Percentage (\%) \\
\hline Age & & 35.6 \\
\hline 19-28 years & 26 & 32.9 \\
\hline $29-38$ years & 24 & 21.9 \\
\hline $39-48$ years & 16 & 9.6 \\
\hline$>49$ years & 7 & 89.0 \\
\hline Nationality & 65 & 11.0 \\
\hline Malaysian & 8 & 8.2 \\
\hline Indonesian & & 2.7 \\
\hline Position & 6 & 89.0 \\
\hline Site Manager & 2 & 24.7 \\
\hline Safety Officer & 65 & 28.8 \\
\hline General Workers & & 16.4 \\
\hline Experience & 18 & 30.1 \\
\hline $1-3$ years & 21 & $100 \%$ \\
\hline $4-6$ years & 12 & \\
\hline 7-9 years & 22 & \\
\hline$<10$ years & 73 & \\
\hline Total N & & \\
\hline & & \\
\hline
\end{tabular}

Table 4 shows the results of the Cronbach's alpha reliability test for all variables which are safety performance, safety awareness, time barriers, and management commitment. The highest 
INTERNATIONAL JOURNAL OF ACADEMIC RESEARCH IN BUSINESS AND SOCIAL SCIENCES

Vol. 8, No. 9, Sept. 2018, E-ISSN: 2222-6990 @ 2018 HRMARS

Cronbach's alpha for reliability test was for time barriers at .855 , followed by management commitment (.791), safety performance (.772), and safety awareness (.664). By referring to Sekaran and Bougie (2016), the test shows that all variables are good and reliable.

Table 4: Cronbach's Alpha for the Reliability Test

\begin{tabular}{|c|c|}
\hline VARIABLE & CRONBACH'S ALPHA \\
\hline Safety Performance & .772 \\
\hline Safety Awareness & .664 \\
\hline Time Barriers & .885 \\
\hline Management Commitment & .791 \\
\hline
\end{tabular}

The researchers used correlation analysis to answer the first research questions. Table 5 shows the results of the Pearson Correlation Analysis test, indicating that first, there is a positive, strong, and significant relationship between safety performance and safety awareness $(r=.739, p<.05)$. Next, there is a positive, moderate and significant relationship between safety performance and time barriers $(r=.574, p<.05)$. Finally, there is a positive, weak, and significant relationship between safety performance and management commitment $(r=.326, p<.05)$.

able 5: Pearson Correlation Analysis

\begin{tabular}{|c|c|c|c|c|c|}
\hline & & $\begin{array}{c}\text { Safety } \\
\text { Performance }\end{array}$ & $\begin{array}{c}\text { Safety } \\
\text { Awareness }\end{array}$ & $\begin{array}{c}\text { Time } \\
\text { Barriers }\end{array}$ & $\begin{array}{l}\text { Management } \\
\text { Commitment }\end{array}$ \\
\hline $\begin{array}{l}\text { Safety } \\
\text { Performance }\end{array}$ & $\begin{array}{l}\text { Pearson } \\
\text { Correlation } \\
\text { Sig. (2-tailed) } \\
N\end{array}$ & 1 & $\begin{array}{c}.739 * * \\
.000 \\
73\end{array}$ & $\begin{array}{c}.574^{* *} \\
.000 \\
73\end{array}$ & $\begin{array}{c}.326^{*} \\
.005 \\
73\end{array}$ \\
\hline Safety Awareness & $\begin{array}{l}\text { Pearson } \\
\text { Correlation } \\
\text { Sig. (2-tailed) } \\
N\end{array}$ & $\begin{array}{c}.739 * * \\
.000 \\
73\end{array}$ & 1 & $\begin{array}{c}.555^{* *} \\
.000 \\
73\end{array}$ & $\begin{array}{l}.161 \\
.175 \\
73\end{array}$ \\
\hline Time Barriers & $\begin{array}{l}\text { Pearson } \\
\text { Correlation } \\
\text { Sig. (2-tailed) } \\
N\end{array}$ & $\begin{array}{c}.574^{* *} \\
.000 \\
73\end{array}$ & $\begin{array}{c}.555^{* *} \\
.000 \\
73\end{array}$ & 73 & $\begin{array}{l}.246^{*} \\
.036 \\
73\end{array}$ \\
\hline $\begin{array}{l}\text { Management } \\
\text { Commitment }\end{array}$ & $\begin{array}{l}\text { Pearson } \\
\text { Correlation } \\
\text { Sig. (2-tailed) } \\
N\end{array}$ & $\begin{array}{c}.326^{*} \\
.031 \\
73\end{array}$ & $\begin{array}{l}.161 \\
.175 \\
73\end{array}$ & $\begin{array}{l}.246 * \\
.036 \\
73\end{array}$ & 73 \\
\hline
\end{tabular}


INTERNATIONAL JOURNAL OF ACADEMIC RESEARCH IN BUSINESS AND SOCIAL SCIENCES Vol. 8, No. 9, Sept. 2018, E-ISSN: 2222-6990 @ 2018 HRMARS

\section{** Correlation is significant at the 0.01 level (2-tailed) \\ * Correlation is significant at the 0.05 level (2-tailed)}

Finally, the researchers ran the multiple regression analysis test to answer the second research question. As shown in Table 6 , the $R$ square value is .615, which means $61.5 \%$ of the variance in safety performance is explained by the three independent variables, which are safety awareness, time barriers, and management commitment. The remaining $38.5 \%$ is unexplained and might be explained by other variables outside the scope of the study. The model is statistically significant $(F=36.772, p$ $<.05)$.

Table 6: Multiple Regression Analysis (Model Summary)

\begin{tabular}{|c|c|c|c|c|}
\hline Model & $R$ & $R$ Square & $\begin{array}{c}\text { Adjusted R } \\
\text { Square }\end{array}$ & $\begin{array}{c}\text { Std. Error of } \\
\text { the Estimate }\end{array}$ \\
\hline 1 & $.784^{\mathrm{a}}$ & .615 & .598 & .42628 \\
\hline
\end{tabular}

Table 7 shows that safety awareness has a statistically significant correlation with safety performance as $p<.05$ with a positive value of beta (.601), which means with every one unit increase in safety performance, the outcome variable will increase by 0.601 unit. Next, time barriers show a statistically significant correlation with safety performance $p<.05$. Safety awareness has a positive value of beta (.196), which means with every 1 unit increase in safety performance, the outcome variable will increase by 0.196 unit. There is also a significant correlation between management commitment and safety performance as $p<.05$ with a positive value of beta (.181). Lastly, the highest factor that influences safety performance is safety awareness as $\beta=.601$.

Table 7: Multiple Regression Analysis (Coefficients)

\begin{tabular}{|c|c|c|c|c|c|c|}
\hline \multirow{2}{*}{\multicolumn{2}{|c|}{ Model }} & \multicolumn{2}{|c|}{$\begin{array}{l}\text { Unstandardised } \\
\text { Coefficients }\end{array}$} & \multirow{2}{*}{\begin{tabular}{|c|}
$\begin{array}{c}\text { Standardised } \\
\text { Coefficients }\end{array}$ \\
Beta \\
\end{tabular}} & \multirow[b]{2}{*}{$t$} & \multirow[b]{2}{*}{ Sig. } \\
\hline & & $B$ & Std. Error & & & \\
\hline \multirow[t]{4}{*}{1} & (Constant) & -1.114 & .455 & & -2.452 & .017 \\
\hline & Safety Awareness & .586 & .088 & .601 & 6.688 & .000 \\
\hline & Time Barriers & .190 & .089 & .196 & 2.143 & .036 \\
\hline & $\begin{array}{l}\text { Management } \\
\text { Commitment }\end{array}$ & .256 & .109 & .181 & 2.347 & .022 \\
\hline
\end{tabular}

In conclusion, the regression equation that can be used to predict the safety performance at the construction site is as follows:

$$
\begin{gathered}
\text { Safety performance }=-1.114+(0.601 \times \text { Safety Awareness })+(0.196 \times \text { Time Barriers })+(0.181 \times \\
\text { Management Commitment })
\end{gathered}
$$


INTERNATIONAL JOURNAL OF ACADEMIC RESEARCH IN BUSINESS AND SOCIAL SCIENCES Vol. 8, No. 9, Sept. 2018, E-ISSN: 2222-6990 @ 2018 HRMARS

\section{Discussion and Conclusion}

As shown in the findings section, there is a positive, strong, and significant relationship between safety performance and safety awareness. Besides, the multiple regression analysis proved that safety awareness is statistically significant and correlated with safety performance, which means that an increase in safety awareness will enhance the safety performance. The finding is similar to the previous studies conducted by other researchers such as Fang et al. (2004), who believed that there is a positive relationship between safety awareness and safety performance. Moreover, safety awareness is the most influential factor affecting the safety performance at the construction site. This finding is similar to Nawi et al. (2016) and Vitharana et al. (2015), as the researchers mentioned that safety awareness is the major problem faced at construction sites that leads to poor safety performance.

There is a significant positive relationship between safety performance and time barriers and management commitment. The result is in line with the previous research conducted by Couto et al. (2017) and Kelloway and Cooper (2011), who explained that time barriers significantly increase the risk of safety performance. On the other hand, Tam, Zeng, and Deng (2004) and Abdul-Rashid et al. (2007) concluded that safety performance is affected by low management commitment.

The researchers offer some recommendations for enhancing safety performance of the construction companies. First, there should be regular inspection and monitoring of the company's safety level to ensure safe work practices are being maintained at the construction site. Getting employees' assistance on safety monitoring will lead to high awareness and employees will learn more about safety hazards. Second, the management has to conduct proper safety education and training, as these are important tools to inform workers about workplace hazards so they can work more safely and be more productive and effective. By conducting proper safety education and training, the company can instill the knowledge and skills needed for the workers to do their work safely. Moreover, proper safety training can reduce insured losses due to accidents, administrative penalties or fines, and litigation. The management has to take "prevention is better than cure" steps to mitigate losses from the occurrence of accidents. Finally, the company has to engage the workers through effective communication and coordination so that the workers are aware of the types of hazards that might arise and that the procedure that needs to be undertaken is to avoid or control. The supervisor will not always be at the site, so the workers have to know how to react in the event of an accident. The language barriers in communication with foreign workers can be eliminated if the management makes two-way communication with those workers and obtain their feedbacks on any safety procedures.

For future research, the researchers propose that the same study will be applied to other contexts or other industries. Future research could also consider other variables that may explain the safety performance of a company, for example, the attitude of the workers. Lastly, future research could adopt a qualitative methodology to understand in-depth the safety performance phenomenon. 
INTERNATIONAL JOURNAL OF ACADEMIC RESEARCH IN BUSINESS AND SOCIAL SCIENCES Vol. 8, No. 9, Sept. 2018, E-ISSN: 2222-6990 @ 2018 HRMARS

\section{Corresponding Author}

Saida Farhanah Sarkam, Faculty of Business and Management UiTM Melaka, Alor Gajah Campus, 78000 Melaka, Malaysia. saidafarhanah@melaka.uitm.edu.my

\section{References}

Abdul-Rashid, I., Bassioni, H., \& Bawazeer, F. (2007). Factor affecting safety performance in large construction contractor in Egypt. In Proceedings of 23 $3^{\text {rd }}$ Annual ARCOM Conference, 3-5 September 2007, Belfast, UK, Association of Researches in Construction Management, pp.661-670

Aksorn, T., \& Hadikusumo, B. H. W. (2008). Critical success factors are influencing safety program performance in Thai construction projects. Safety Science, 46(4), 709-727.

Bernama. (2017, April 11). CIDB sees construction sector growing $8 \%$ to RM170b in $\quad 2017$. The Star Online. Retrieved from https://www.thestar.com.my/business/business-news/2017/04/11/cidb-sees-constructi onsector-growing-8pct-to-rm170b-in-2017/

Cheng, E. W., Ryan, N., \& Kelly, S. (2012). Exploring the perceived influence of safety management practices on project performance in the construction industry. Safety Science, 50(2), 363-369.

Choudhry, R. M., \& Fang, D. P., \& Mohamed, S. (2007). The nature of safety culture: A survey of the state-of-the-art. Safety Science, 45(10), 993-1012.

CIDB. (2018). Retrieved from http://www.cidb.gov.my/index.php/en/

Couto, J. P., Santos, F. J. B., \& Rabbani, E. R. K. (2017). How time constraints affect safety conditions at construction sites: Analysis of the perception of Portuguese construction participants. Electronic Journal of Geotechnical Engineering, 22(02), 563-576.

Durdyev, S., Mohamed, S., Lay, M. L., \& Ismail, S. (2017). Key factors affecting construction safety performance in developing countries: Evidence from Cambodia. Construction Economics and Building, 17(4), 48-65.

Fang, D. P., Xie, F., Huang, X. Y., \& Li, H. (2004). Factor analysis-based studies on construction workplace safety management in China. International Journal of Project Management, 22(1), 43-49.

Ghani, E. M. K., Hamid, E. D. Z., Rahim, E. A. H., Kamar, E. K. A., Rahman, M. A. (2008). Safety in Malaysian Construction: The challenges and initiative. Jurutera Feature, 17-19.

Haslam, R. A., Hide, S. A., Gibb, A. G. F., Gyi, D. E., Pavitt, T., Akinston, S., \& Duff, A. R. (2005). Contributing factors in construction accidents. Applied Ergonomic, 36(4), 401-415.

Hsu, S. H., \& Lee, C. C. (2014). Safety management in a relationship-oriented culture. International Journal of Occupational Safety and Ergonomics (JOSE), 18(1):35-45.

Kelloway, E. K., \& Cooper, C. L. (2011). Occupational Health and Safety for Small and Medium Sized Enterprises. Retrieved from http://QUT.eblib.com.au/patron/FullRecord.aspx?p=807375

Khan, K. M. I., Suguna, K., \& Raghunath, P. N. (2015). Factors analysis on safety management in construction projects. Asian Journal of Applied Sciences, 3(4), 755-766. 
INTERNATIONAL JOURNAL OF ACADEMIC RESEARCH IN BUSINESS AND SOCIAL SCIENCES

Vol. 8, No. 9, Sept. 2018, E-ISSN: 2222-6990 @ 2018 HRMARS

Krejcie, R.V., \& Morgan, D.W. (1970). Determining sample size for research activities. Educational and Psychological Measurement, 30, 607-610.

Lin, J., \& Mills, A. (2001). Measuring the occupational health and safety performance of construction companies in Australia. Facilities, 19(3), 131-139

Masood, R., \& Choudhry, R. M. (2011). Measuring safety climate to enhance safety culture in the construction industry of Pakistan. In CIB W099 Safety and Health in Construction Conference: Prevention: Means to the End of Construction Injuries, Illnesses, and Fatalities, 1243-1249.

Nawi, M. N. M., Ibrahim, S. H., Affandi, R., Rosli, N. A., \& Basri, F. M. (2016). Factor affecting safety performance construction industry. International Review of Management and Marketing, 6(8S), 280-285.

OSHA. (2016). Recommended practices for safety \& health programs in construction. Retrieved from https://www.osha.gov>docd>8524_OSHA.

OSHA. (2017). OSHA Compliance Guidance on Training. Retrieved from https://www.osha.gov/dte/training_policy.html

Peyton, R.X., Rubio, T.C. (1991). Construction Safety Practices and Principles. New York: Van Nostrand Reinhold.

Sekaran, U., \& Bougie, R. (2016). Research methods for business; a skill-building approach (7th Ed.). United Kingdom: John Wiley \& Sons Ltd.

Tam, C. M., Zeng, S. X., \& Deng, Z.M. (2004). Identifying elements of poor construction safety management in China. Safety Science, 42(7), 133-140.

Thye, L. L. (2018, January 14). Construction site accidents rising. New Straits Times. Retrieved from https://www.nst.com.my/opinion/letters/2018/01/324931/construction-siteaccidents- rising

Wong, J. Y. Y., Gray, J., \& Sadiqi, Z. (2015). Barriers to Good Occupational Health \& Safety (OHS) Practices by Small Construction Firms. Journal of Construction Management, 30(I), 55-66.

Yilmaz, F., \& Celebi, U. B. (2015). The importance of safety in construction sectors: costs of occupational accidents in construction sites. Business and Economics Research Journal, 6(2), 25.

Zack, J. (2018, Mar 9). Accident at construction site kills one, injures four. The Star Online. Retrieved from https://www.thestar.com.my/news/nation/2018/03/09/accident-atconstruction-site-kills-one-injures-four/ 